\title{
Identification of the spatio-temporal and fluvial-pluvial sources of flood inundation in the Lower Mekong Basin
}

\author{
Sophal Try ${ }^{1,2^{*}}\left(\mathbb{D}\right.$, Takahiro Sayama ${ }^{1}$, Chantha Oeurng ${ }^{2}$, Ty Sok ${ }^{2}$, Steven Ly ${ }^{1}$ and Sovannara Uk ${ }^{3}$
}

\begin{abstract}
Identification of the sources of the spatio-temporal information of flooding is important for flood control and understanding the water dynamic. Flood disasters are generally caused by two main sources: fluvial and pluvial flooding. However, there is a gap in information and challenge of such particular information in the Mekong River Basin (MRB) known as the largest river basin in Southeast Asia. This paper aims to analyze the spatio-temporal hydrograph separations of flooding and to determine the fluvial and pluvial sources of inundation water in the Lower Mekong Basin (LMB) by using a distributed rainfall-runoff-inundation (RRI) model and time-space accounting scheme (T-SAS) method. This study focuses on the two major flood events in 2000 and 2011, whose characteristics were different. The one in 2000 was long in terms of flood duration and it was the historically largest annual total flood water with twice the peak times in July and September. The 2011 flood had the highest flooded water during the peak time; however, its annual total flood water was less than the one in 2000. The results of spatio-temporal sources of flooding indicated that during the flow peak time in 2000 and 2011, the flow at Kratie was mainly contributed by 30-day (67\%) and 100-day (98\%) precipitation from the upstream. The drainage area of the MRB in China, northern Lao PDR, southern Lao PDR and eastern Thailand, and Cambodia and Vietnam contributed to peak flood at Kratie by 13\%, 27\%, 33\%, and $27 \%$ for the 2000 flood and 12\%, 33\%, 38\%, and 16\% for the 2011 flood. The source of inundated water in the LMB was derived from upstream flow (fluvial source) of $35-36 \%$ and local rainfall (pluvial source) of $64-65 \%$. Even though flood events in 2000 and 2011 had different characteristics, the sources of flood inundation in the LMB for both events were majorly from the local rainfall rather than the upstream flow. The large annual flood volume and long during of flooding in 2000 caused severe total economic damages up to 517 million US\$ in the LMB countries (Cambodia, Lao PDR, Thailand, and Vietnam), while the high peak inundated water in 2011 with shorter flood duration caused damages of 493 million US\$.
\end{abstract}

Keywords: Flood inundation, Spatio-temporal separations, Fluvial and pluvial sources, Lower Mekong Basin, RRI model

\section{Introduction}

The Mekong River Basin (MRB) is the largest river basin in Southeast Asia, extending over an extensive area of $795,000 \mathrm{~km}^{2}$ with an enormous average discharge of $14,500 \mathrm{~m}^{3} / \mathrm{s}$ (MRC 2005). One of the dominant features

\footnotetext{
*Correspondence: trysophal001@gmail.com

${ }^{1}$ Disaster Prevention Research Institute, Kyoto University, Kyoto, Japan
}

Full list of author information is available at the end of the article of the MRB lies in its annual flooding which drives not only the exceptionally high productivity and biodiversity in its ecosystem, but also the downstream regions (i.e., the Tonle Sap Lake ecosystem, the Mekong Delta). In a large river system such as MRB, seasonal flows can be quite variable from year to year and the magnitude of the annual hydrograph is not predictable.

While the magnitude of floods is typically quantified by peak discharge, this is not a good enough measure, 
especially in large rivers such as the MRB, since there are other aspects of a flood that are often as important or more important (i.e., duration of the flow, flood volume). It is estimated that almost $80 \%$ of the approximately 70 million people from the four countries in the Lower Mekong Basin (LMB) depend on the river and its rich natural resources for their livelihoods, living in the flood-prone area (Try et al. 2019). Every year, intense rainfall, generated by tropical storms sweeping over the LMB, often causes a rise of water level in tributary catchments, as well as later in the main river channel. Such an event results in severe damages to social infrastructure (e.g., houses, roads, and bridges) and sometimes even leads to loss of human life (ADB 2012). The economic cost of floods, however, varies significantly from country to country. The spatio-temporal information of flooding is important for flood control and understanding the water dynamic, especially for a large and complex system like the MRB.

Extreme rainfall is usually a major factor causing flood damage by two main different mechanisms: pluvial and fluvial floodings (Tanaka et al. 2020). Pluvial flooding happens when the short-term extreme rainfall exceeds infiltration and discharging capacity causing flood in the same area as rainfall. Fluvial flooding refers to the high water level in the river channel from the upper area reaching over the bank height. Generally, pluvial flooding occurs more often, while fluvial flooding could lead to severe economic damage (Moftakhari et al. 2017). Spatio-temporal evaluation of flood and its related damage is important to comprehend its impact and reduction strategy preparation (Duan et al. 2016). Understanding the primary cause of flooding provided essential information to support decision makers in mitigating floods in the future (Zou et al. 2020). An effective flood management could be used to improve sustainable water management and ecosystem conditions for cross-border river basin such as the MRB (Duan et al. 2019, 2020).

Hydrograph separation is referred to as various analyses commonly performed to decompose hydrographs into sub-hydrographs and considered as the first step to catchment-scale water balance analysis. In hydrology, hydrograph separation and the identification of the baseflow contribution to streamflow is not a new subject (Pelletier and Andréassian 2020). There are various hydrograph separation methods which range from empirical to analytical and physical methods (Buttle 1994; Uhlenbrook and Hoeg 2003; Tan et al. 2009; Mei and Anagnostou 2015; Pelletier and Andréassian 2020). The time (when) and space (where) of rainfall during and before flooding are the principal information for identifying the cause of floods. In the small-scale river basin, the lag time between rainfall and flooding is short. However, this lag time can be delayed to a long period in the largescale river basin. For example, Sayama et al. (2015a, b) found that 6-month rainfall showed the highest correlation to peak inundation volume in the Chao Phraya River Basin in Thailand. Try et al. (2020a) determined that 3-month precipitation had the highest correlation to peak discharge and inundation volume in the Mekong River Basin (MRB).

Water balance analysis not only provides an understanding of the water cycle in a river basin, but also is an important step for water resource planning and management. Precipitation is one of the most important variables for the water balance analysis. The future change of intensity and frequency of precipitation will affect the flood characteristic in the river basin. Climate change impacts on water resources have also been reported in the assessment reports of the Intergovernmental Panel on Climate Change (IPCC 2014). Climate change has an impact on the hydrological system by altering the hydrological cycle and precipitation patterns, thereby affecting the overall availability of freshwater resources (Pendergrass et al. 2017; Halofsky et al. 2018; Muir et al. 2018; Jain and Singh 2018; Wu et al. 2020). Given the spatio-temporal dynamics of precipitation, evapotranspiration, surface runoff, and baseflow components, and their alterations due to impending climate change, it is important to estimate the spatio-temporal dynamics of flooding and water balance analysis.

This paper aims to investigate the spatio-temporal sources of rainfall causing flooding through a distributed rainfall-runoff-inundation (RRI) model and a time-space accounting scheme (T-SAS) on the two large historical flood events in 2000 and 2011 which were classified as the largest historical flood events in the MRB (MRC 2005; ADB 2012). This paper also provides further understanding of flood dynamics and the information of fluvial and pluvial sources contributed to flooding inundation in the LMB.

\section{Methodology \\ Study area}

The MRB, the largest river basin in Southeast Asia and one of the world's largest river systems with a catchment area of 795,000 $\mathrm{km}^{2}$, has its main river flowing over a distance of nearly $5000 \mathrm{~km}$ through six countries, including China, Myanmar, Thailand, Lao PDR, Cambodia, and Viet Nam (MRC 2005). The climate of the MRB is dominated by the Southwest Monsoon, generating two distinguished seasons, namely the wet and dry seasons, usually with the starting of monsoon season in May and ending in late September or early October. The mean annual discharge of the Mekong is approximately $475 \mathrm{~km}^{3}$. The Mekong mainstream can be divided into six main "reaches", taking into account the consideration of 
hydrological regimes, physiography, land use, and existing planned and potential resource development. Most of the water contribution to the Mekong flows comes from Laos, particularly the tributaries that enter downstream of Vientiane Nongkhai. Most areas inside the LMB were floodplain with low elevation (Fig. 1) and were identified as flood-prone areas (Try et al. 2018a, 2019).

\section{Flood inundation model}

This study used a rainfall-runoff-inundation (RRI) model capable of simulating rainfall-runoff and flood inundation simultaneously (Sayama et al. 2012, 2015a, 2015b). The RRI model is a two-dimensional distributed model dealing with diffusive wave approximation equations enabling considering the interaction of water exchange from the downstream cell and upstream cell (i.e., backwater effect), which cannot be taken into account in the distributed model based on kinematic approximation. The RRI model computes runoff using saturated subsurface flow for the mountainous region and Green-Amp infiltration in the floodplain area.

The RRI model simulates unsaturated subsurface flow based on the Darcy equation with a variable hydraulic conductivity $k$. It uses the power form of $k\left(=k_{m}\left(h_{s} / d_{m}\right)^{\beta}\right)$, where $k_{m}$ is the saturated hydraulic conductivity in capillary pores, $\beta$ is an exponent parameter, $d_{m}$ is the maximum water content in capillary pores, and $h_{s}$ is water content represented by an equivalent water height. Once $h_{s}$ exceeds $d_{m}$, water also flows in non-capillary pores, parameterized by their saturated hydraulic conductivity $k_{a}$. Furthermore, when $h_{s}$ exceeds $d_{a}$ or the maximum water content in the soil layer, saturated excess overland flow also occurs on the soil layer. The derived equation is summarized as follows:

$$
q_{x}=\left\{\begin{array}{l}
-k_{m} d_{m}\left(\frac{h_{s}}{d_{m}}\right)^{\beta} \frac{\partial H_{s}}{\partial x}, \quad\left(h_{s} \leq d_{m}\right) \\
-k_{a}\left(h_{s}-d_{m}\right) \frac{\partial H_{s}}{\partial x}-k_{m} d_{m} \frac{\partial H_{s}}{\partial x}, \quad\left(d_{m}<h_{s} \leq d_{a}\right) \\
-\frac{1}{n}\left(h_{s}-d_{a}\right)^{5 / 3} \sqrt{\left|\frac{\partial H_{s}}{\partial x}\right|} \operatorname{sgn}\left(\frac{\partial H_{s}}{\partial x}\right)-k_{a}\left(h_{s}-d_{m}\right) \frac{\partial H_{s}}{\partial x}-k_{m} d_{m} \frac{\partial H_{s}}{\partial x}, \quad\left(d_{a}<h_{s}\right)
\end{array},\right.
$$

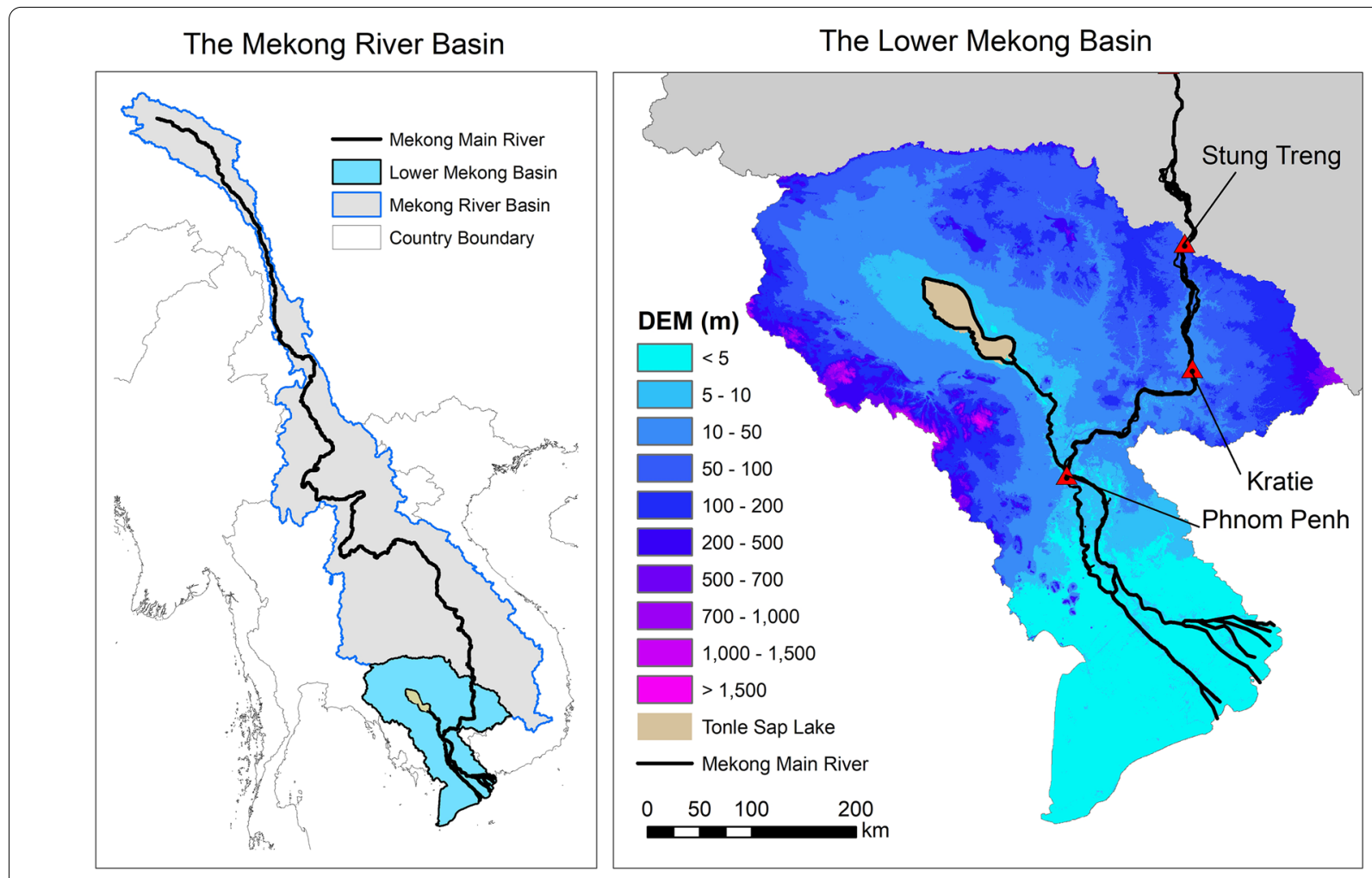

Fig. 1 The location of the study area: the Mekong River Basin (left) and the Lower Mekong River Basin (right) 
where $q_{x}$ is the $x$-direction discharge (the same equation is used for $y$-direction), $k_{a}$ is the lateral saturated hydraulic conductivity, $d_{a}$ is the soil depth times effective porosity, $n$ is Manning's roughness, and sgn is the signum function. To assure continuity of the discharge change, lateral hydraulic conductivity in capillary pores can be estimated as $k_{m}=k_{a} / \beta$, so that $k_{m}$ is no longer the independent parameter. The RRI model uses the hydraulic gradient $(\partial H / \partial x)$ in diffusive wave approximations.

The RRI model has been widely used for different purposes in various study areas confirming its good performance and ability to simulate flood inundation. For example, the RRI model was used to study the characteristics of the 2011 flood (Sayama et al. 2015b) and hydrologic sensitivity of rainfall-runoff and inundation (Sayama et al. 2015a) in the Chao Phraya River Basin, Thailand. Try et al. (2018b) used the RRI model for reproducing a historical large flood event in 2000 in the MRB, and Try et al. (2020b) evaluated the performance of satellite-based precipitation products. Perera et al. (2017) and Try et al. (2020b) used the RRI model to evaluate the effects of climate change in the LMB by considering various representative concentration pathways (RCPs) and sea surface temperature (SST) scenarios. Moreover, Try et al. (2020a) used the RRI model for the projection of extreme flood inundation events in the MRB. In addition, the RRI model has been successfully applied for flood inundation study in other river basins, including Nyaungdon Area (Khaing et al. 2019) and Bogo River Basin (Bhagabati and Kawasaki 2017) in Myanmar, Batanghari River Basin in Indonesia (Yamamoto et al. 2020), Kabul River Basin in Afghanistan (Sayama et al. 2012), Kalu and Mundeni River Basins in Sri Lanka (Rasmy et al. 2019), Kelantan River Basin in Malaysia (Chong et al. 2017; Tam et al. 2019), and other river basins in Japan (Sayama et al. 2019, 2020).

This study used the river geometry whose shapes are noted by river width $W(\mathrm{~m})$ and river depth $D(\mathrm{~m})$ as in the following equations:

$$
\begin{gathered}
W=C_{W} A^{S_{W}}, \\
D=C_{D} A^{S_{D}},
\end{gathered}
$$

where $C_{W}, S_{W}, C_{D}$ and $S_{D}$ are river geometry parameters, and $A$ is the upstream contributing area $\left(\mathrm{km}^{2}\right)$. Try et al. (2018b) calculated the geometry coefficients $C_{W}, S_{W}, C_{D}$, and $S_{D}$ with values of $0.0015,0.7491,0.0520$, and 0.7596 , respectively, for the MRB. This study employed the precipitation dataset from GPCC (Ziese et al. 2018) whose performance for discharge and flood simulations was checked and validated by Try et al. (2020a, 2020b, 2020c). The evapotranspiration dataset was taken from the Japanese 55-year Reanalysis dataset (JRA-55) with 3-hourly and $0.5625^{\circ}$ resolution (Kobayashi et al. 2015). The topography data including digital elevation model (DEM), flow direction (DIR), and flow accumulation (ACC) derived from Multi-Error-Removed-Improved-Terrain (MERIT DEM, Yamazaki et al. 2017) and land use from MODIS (product: MCD12Q1) for 2000 (Friedl et al. 2010) were used as input to the RRI model in this study. The detailed values of input parameters of the RRI model can be found in Table 1.

To evaluate the model performance in simulation of river discharge, the coefficient of determination $\left(R^{2}\right)$ and Nash-Sutcliffe efficiency (NSE) were used:

$$
\begin{aligned}
& \text { NSE }=1-\frac{\sum\left(Q_{\text {sim }}(t)-Q_{\text {obs }}(t)\right)^{2}}{\sum\left(Q_{\text {obs }}(t)-\overline{Q_{\text {obs }}}\right)^{2}}, \\
& R^{2}=\frac{\sum\left(\left(Q_{\text {sim }}(t)-\overline{Q_{\text {sim }}}\right)\left(Q_{\text {obs }}(t)-\overline{Q_{\text {obs }}}\right)\right)^{2}}{\sum\left(Q_{\text {sim }}(t)-\overline{Q_{\text {sim }}}\right)^{2} \sum\left(Q_{\text {obs }}(t)-\overline{Q_{\text {obs }}}\right)^{2}},
\end{aligned}
$$

where $Q_{\text {sim }}(t)$ and $Q_{\text {obs }}(t)$ are the simulated and observed discharge at time step $t$, and $\overline{Q_{\text {sim }}}$ and $\overline{Q_{\text {obs }}}$ are the simulated and observed average discharge. The values of

\begin{tabular}{|c|c|c|c|c|}
\hline Parameters & Symbol & Unit & Mountains & Plains \\
\hline Manning's coefficient for slope & $n$ & $\left(m^{-1 / 3} s\right)$ & 0.4 & 0.015 \\
\hline Soil depth & $d$ & (m) & 1.0 & - \\
\hline Lateral saturated hydraulic conductivity & $k_{a}$ & $(\mathrm{~m} / \mathrm{s})$ & 0.1 & - \\
\hline Parameter of unsaturated hydraulic conductivity & $\beta$ & - & 9.0 & - \\
\hline Vertical hydraulic conductivity & $k_{v}$ & $(\mathrm{~cm} / \mathrm{h})$ & - & 0.06 \\
\hline Soil porosity & $\varphi$ & - & - & 0.6 \\
\hline Wetting front soil suction head & $S_{f}$ & - & - & 0.273 \\
\hline Manning's coefficient for river & $n_{\text {river }}$ & $\left(m^{-1 / 3} s\right)$ & 0.03 & \\
\hline
\end{tabular}
NSE and $R^{2}$ are 1 for the perfect prediction of model simulation.

Table 1 The values of parameter setting of the RRI model used in the study 
To evaluate the model performance of model for simulation of inundation extent, the statistical indicators of true ratio (TR) and hit ratio (HR) were used and defined as the following:

$$
\begin{aligned}
& \mathrm{TR}=\frac{\mathrm{IC}_{\mathrm{obs}} \cap \mathrm{IC}_{\text {sim }}}{\mathrm{I} C_{\text {sim }}}, \\
& \mathrm{HR}=\frac{\mathrm{IC}_{\text {obs }} \cap \mathrm{IC}_{\text {sim }}}{\mathrm{IA}_{\mathrm{obs}}},
\end{aligned}
$$

where $\mathrm{IC}_{\mathrm{sim}}$ and $\mathrm{IC}_{\mathrm{obs}}$ are the number of inundated cell from model simulation and MODIS observation data. Both TR and HR become 1 for the estimation of perfect overlap inundation area.

\section{T-SAS method}

To analyze the temporal and spatial sources of water and their flow path, this study used a time-space accounting scheme (T-SAS, Sayama and McDonnell 2009) to assess the dynamic of residence space and time sources of flow from the RRI model. The T-SAS solved the time-space hydrograph that tracks the flow contributed by rainwater originated from certain time classes and spatial zones as illustrated in Fig. 2. By providing the number of temporal classes $(T)$ and spatial zones $(S)$, the dimension of the TSAS matrix of $T \times S$ is assigned for each grid cell.

The matrices of temporal and spatial sources are continuously updated by draining the water from the upper

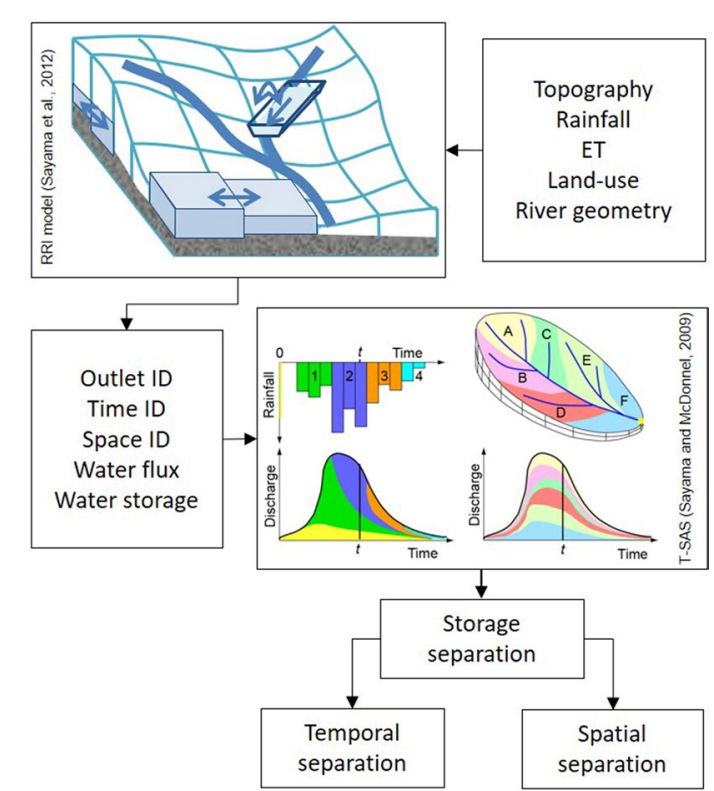

Fig. 2 Schematic diagram of the RRI model and the T-SAS method for this study separation of the temporal and spatial hydrograph components area to the lower area until the target outlet location. The storage elements must be defined at each grid cell and each flow path independently in the RRI model (Fig. 2). In the RRI model, flow at river grid cells is also considered as one of the storage elements. For a surface and subsurface slope grid cell and based on the storage and discharge relationship given by Eq. (1), there are three different storage elements comprising capillary and noncapillary pores and the soil surface. Then T-SAS assumes that the water stored in each element is mixed according to advection fluxes calculated by the hydrologic model, which results in the following mass balance equation.

$$
\begin{aligned}
\frac{\mathrm{d} v_{s}(i, j, k)}{\mathrm{d} t}= & \sum_{l=1}^{L} q_{s}(l, j) \frac{v_{s}(l, j, k)}{V_{s}(l, j)}-\sum_{m=1}^{M} q_{s}(i, j) \frac{v_{s}(i, j, k)}{V_{s}(i, j)} \\
& +p(i, k)-\left(e(i, j)+r_{s g}(i, j)\right) \frac{v_{s}(i, j, k)}{V_{s}(i, j)} \\
& +r_{g s}(i, j) \frac{v_{g}\left(i, j_{g}, k\right)}{V_{g}\left(i, j_{g}\right)},
\end{aligned}
$$

where $v_{s}(i, j, k)$ is the water volume at grid cell $i$ in element $j$ corresponding to the separating component $k$. For the subsurface and surface layer, element $j$ can be a capillary pore $(j=1)$, or a non-capillary pore in the soil layer $(j=2)$ and on the surface $(j=3)$ in the RRI model. The variable $V_{s}(i, j)$ represents the total volume of stored water at grid cell $i$ and $j$-th element. The variable $q_{s}(i, j)$ is the discharge from the $i$-th grid cell, therefore the first term on the right side of Eq. (8) corresponds to inflows from surrounding grid cells $l(l=1, \ldots L)$ to the $i$-th grid cell at the $j$-th element, while the second term represents all outflows (with the number of outflow components $M$ ) from the $i$-th grid cell at the $j$-th element. The variable $p(i, k)$ is rainfall having the separating component information of $k$. The variables $e(i, j)$ and $r_{s g}(i, j)$ are evapotranspiration and recharge to bedrock groundwater from the $i$-th grid cell and the $j$-th element. Note that precipitated water is assumed to be mixed with surface water if surface water exists, otherwise it is mixed with the subsurface flow in the non-capillary soil layer. In the case of zero water storage in the non-capillary layer, the precipitated water is mixed with capillary water. The T-SAS program numerically integrates the differential equation using the fifth-order Runge-Kutta algorithm with adaptive time step control (Cash and Karp 1990), which is used also for numerical integration in the RRI model (Sayama et al. 2012, 2015a, 2015b). With this explicit scheme, all terms on the right side of Eq. (8) are approximated from the previous time step. This study classifies the spatial separation of four main zones and temporal discrete based on $0-10$ days, $11-30$ days, $31-60$ days, $61-100$ days, and 
more than 100 days prior to the peak time of river flow at Kratie for flood events in 2000 and 2011.

\section{Fluvial and pluvial sources of flooding}

This section presents the method to identify the fluvial and pluvial sources of flood inundation in the LMB. In this study, the components to be considered in flood inundation modeling of the RRI in the LMB are local rainfall, local evapotranspiration, and boundary discharge condition (discharge at Stung Treng). The fluvial inundation water contributed by upstream flow was taken from the simulation of the RRI by considering only boundary conditions of discharge and ignoring local rainfall and evapotranspiration (Eq. 9). The pluvial inundation that happened from local rainfall was derived from the simulation of the RRI model using input local rainfall subtracted by the inundation caused by upstream discharge (Eq. 10).
Fluvial inundation water $=\operatorname{RRI}\left(Q_{\text {upstream }}\right)$.

$$
\begin{aligned}
\text { Pluvial inundation water }= & \operatorname{RRI}\left(Q_{\text {upstream }}, R, E T\right) \\
& -\operatorname{RRI}\left(Q_{\text {upstream }}\right) .
\end{aligned}
$$

\section{Results}

\section{Model simulation performance}

The performance of the RRI model was assessed in terms of river discharge and flood inundation extent for the two large flood events in 2000 and 2011. This study used statistical indicators of coefficient of determination $\left(R^{2}\right)$ and Nash-Sutcliffe efficiency (NSE) to evaluate the model performance for river discharge. To evaluate the model performance of inundation extent, the statistical indices of true ratio (TR) and hit ratio (HR) were used. Figure 3 shows a comparison of simulated and observed discharge at Kratie at which the
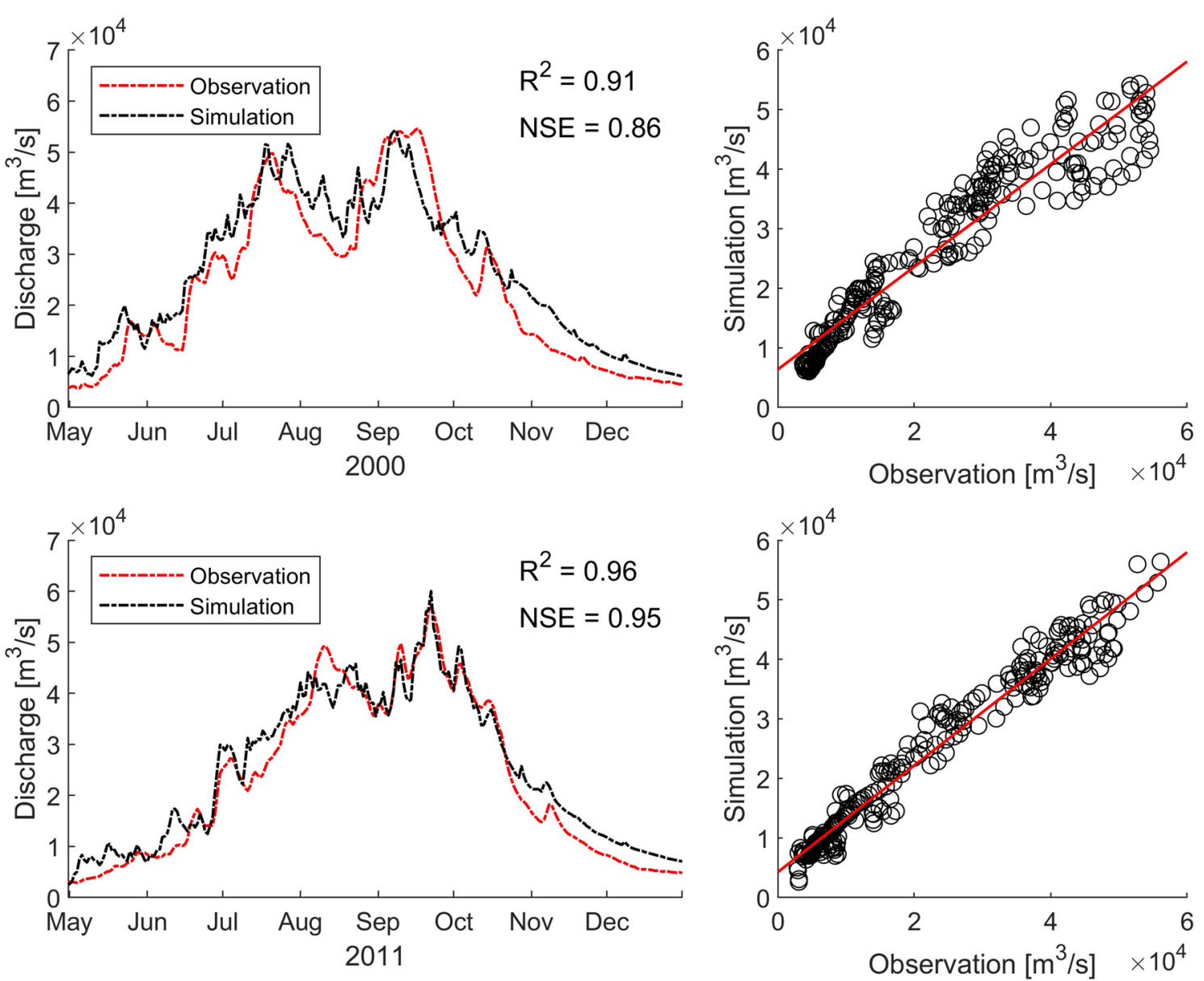

Fig. 3 Time series comparison (left) and scatter plot (right) of simulated and observed discharge at Kratie for 2000 (upper) and 2011 (lower) 

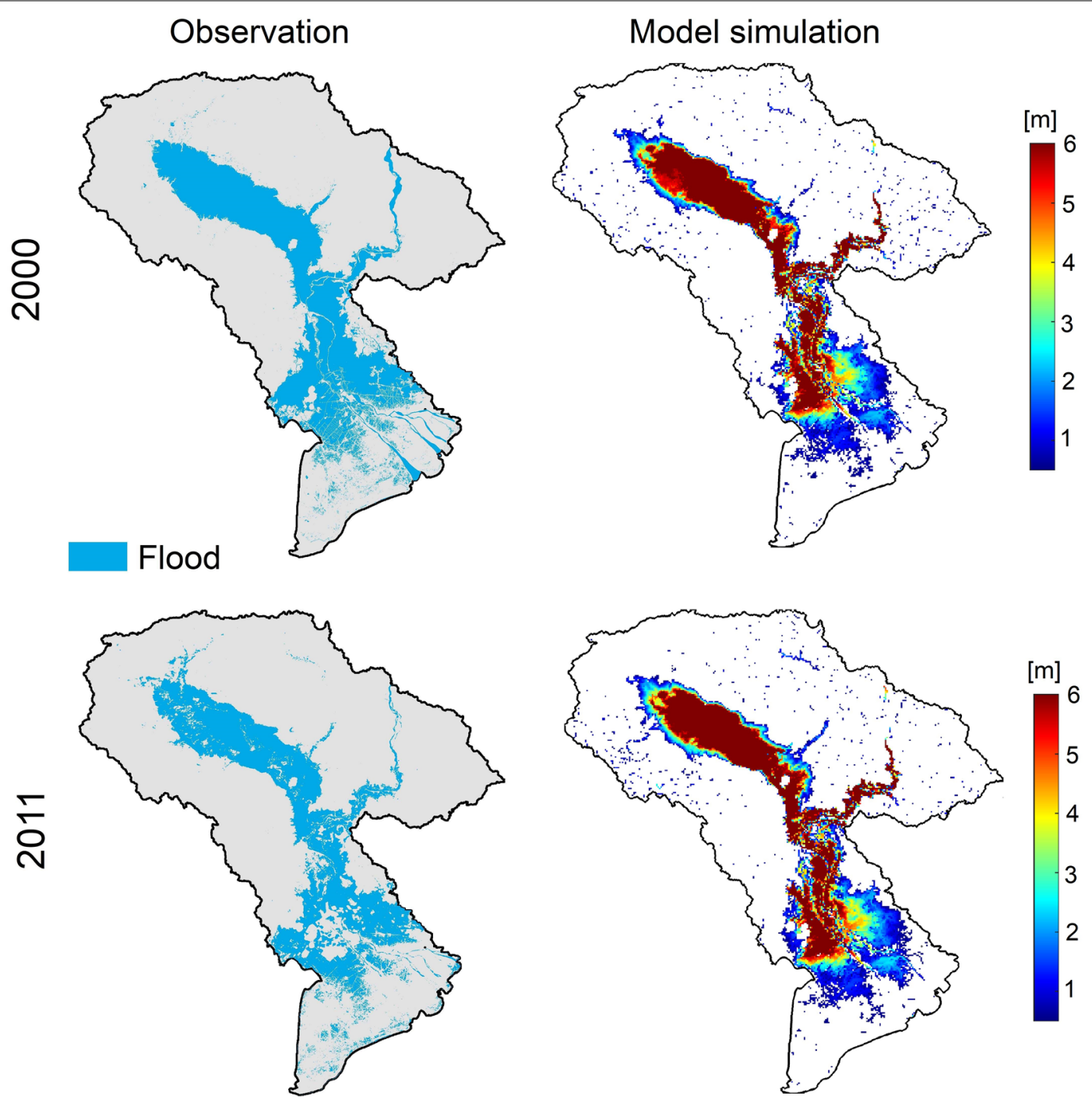

Fig. 4 Simulation and observation of inundation in the LMB for 2000 and 2011

spatio-temporal hydrograph separation is performed in the next section. The results of river discharge showed a satisfactory performance with $R^{2}=0.91(0.96)$ and $\mathrm{NSE}=0.86$ (0.95) for 2000 (2011) flooding. In addition, the spatial performance of simulated and observed flood inundation in the LMB is displayed in Fig. 4 for 2000 and 2011 flood events. The accuracy of spatial performance of flood inundation were $\mathrm{TR}=0.76$ and $\mathrm{HR}=0.83$ for 2000 , and $\mathrm{TR}=0.70$ and $\mathrm{HR}=0.89$ for 2011.

\section{Targeted flood events featuring long-term water balance}

Besides the simulation of two large flood events in 2000 and 2011, the long-term simulation from 1982 to 2016 was conducted to determine the components of water balance in the MRB and to compare these events with floods in the other years. Figure 5 shows the water balance in the MRB of rainfall, evapotranspiration, runoff, and basin storage water. In addition, the inundation in the LMB was also calculated. During the simulation period of 1982-2016, the average annual basin rainfall was $1492 \mathrm{~mm}$, while the rainfall in 2000 and 2011 was higher than the other years with the annual accumulated values of $1809 \mathrm{~mm}$ and $1734 \mathrm{~mm}$, respectively. The basin evapotranspiration was $923 \mathrm{~mm}$ for the average, $959 \mathrm{~mm}$ for 2000, and $903 \mathrm{~mm}$ for 2011. Similar to rainfall and runoff, the basin storage in 2000 and 2011 was high among the considered period. 

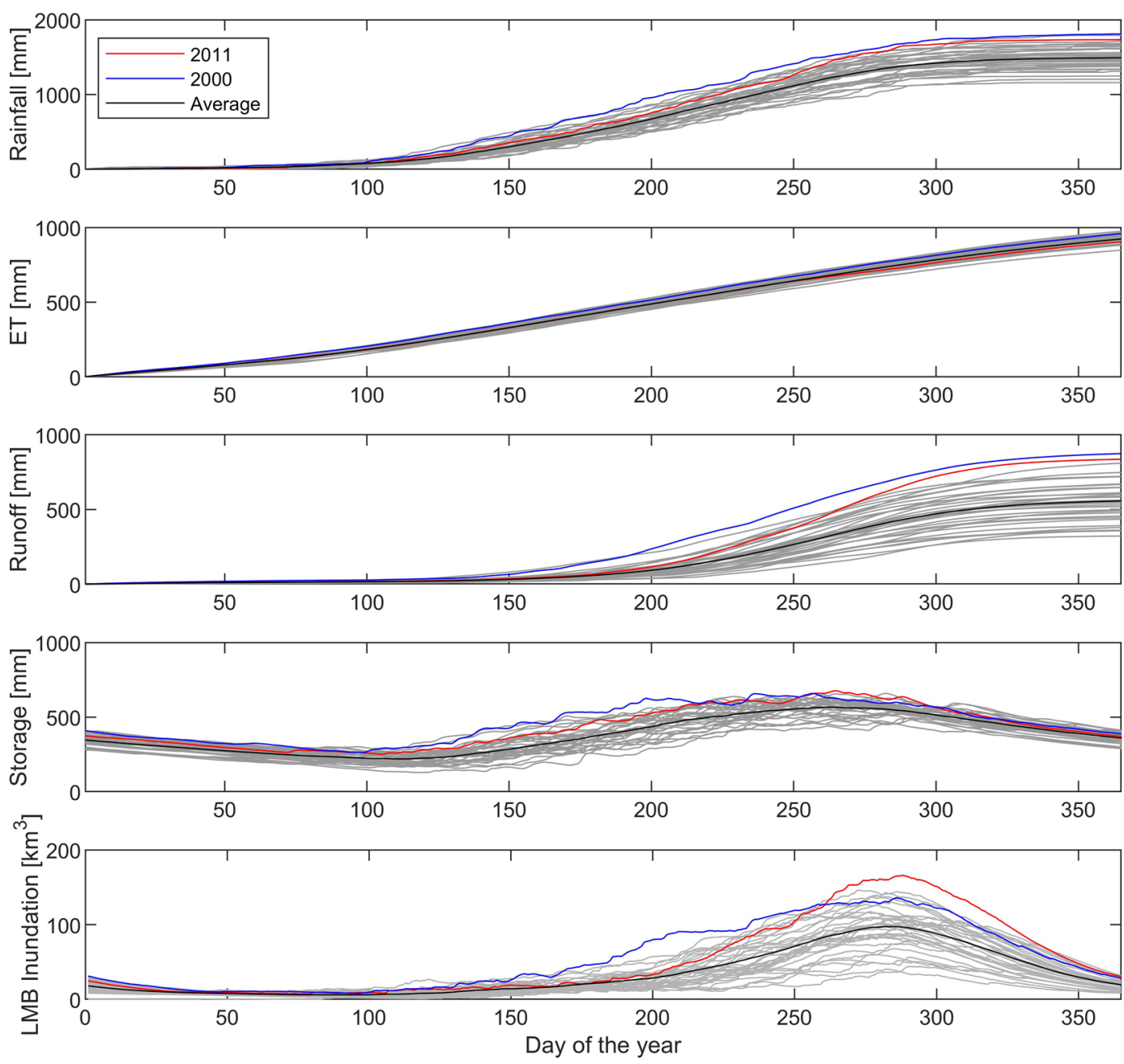

Fig. 5 Simulated water balance components for 2000 (blue lines), 2011 (red lines), average values (black lines), and other 35 years during $1982-$ 2016 (gray lines): cumulative rainfall, cumulative evapotranspiration, cumulative basin runoff, basin storage volume for the MRB, and inundation water volume in the LMB

The annual precipitation in 2000 flood was higher than the one in 2011 by $4.3 \%$; as a result, the total annual runoff was estimated to be higher in 2000 by $4.4 \%$ compared with 2011 (i.e., total runoff of $874 \mathrm{~mm}$ and $837 \mathrm{~mm}$ for 2000 and 2011 floods). However, the peak discharge at Kratie in 2011 was found to be $10 \%$ higher than the 2000 flood $\left(60,007 \mathrm{~m}^{3} / \mathrm{s}\right.$ for 2011 and $54,319 \mathrm{~m}^{3} / \mathrm{s}$ for 2000). In addition, the peak inundation extent and flood volume in the LMB were also estimated to be higher in 2011 by $3.25 \%\left(39,365 \mathrm{~km}^{2}\right.$ and $\left.38,126 \mathrm{~km}^{2}\right)$ and $11.2 \%\left(148 \mathrm{~km}^{3}\right.$ and $134 \mathrm{~km}^{3}$ ) than the one in 2000 , respectively.

The large annual inundated water and long flood duration in 2000 caused the total economic flood damages in the LMB riparian countries (Cambodia, Lao PDR, Thailand, and Vietnam,) of 517 million US\$, while the large magnitude of 2011 caused economic damages of 493 million US\$ (MRC 2015). To investigate the main cause of the inundation extents and volumes in both flood events in 2000 and 2011, we investigated the temporal and spatial information of the sources of rainfall inside the basin contribute to downstream floodwater of the MRB in the following section.

\section{Time-space hydrograph separation}

After the simulation of the RRI model, the water components for each gridded cell and its spatio-temporal information were recorded in files and recalled again for tracing their pattern in T-SAS for hydrograph separation. Figure 6 illustrates the temporal distribution and separation of discharge during the flood season in the MRB at Kratie for 2000 and 2011. The total flow at Kratie from May to December was 571 and 529 billion $\mathrm{m}^{3}$ of water 

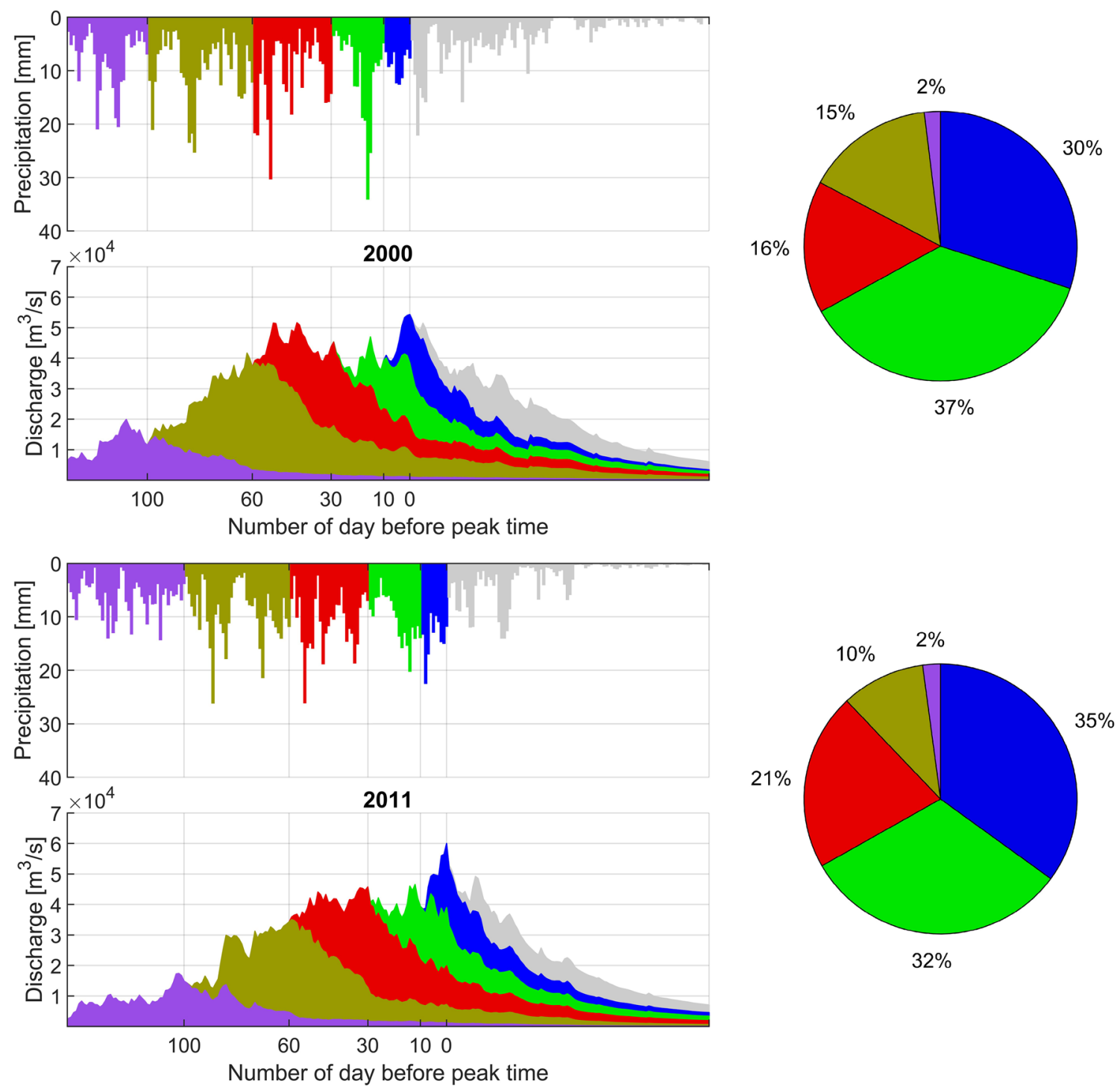

Fig. 6 Hydrograph separation for each temporal zone of precipitation of discharge at Kratie. The right pie charts indicate the percentage of flow contribution from the time zone at the peak time. The color of each temporal duration is consistent among precipitation, discharge, pie charts

for 2000 and 2011. We classified the duration of rainfall as $0-10$ days, $11-30$ days, $31-60$ days, and 61-100 days, more than 100 days prior to peak time to evaluate the temporal sources of rainfall contributed to the flow at Kratie. The results of temporal separation from T-SAS simulation indicated that the majority of rainfall sources of the annual floodwater was within 30-day (67\%) and 100-day (98\%) rainfall before peak time of flow at peak time in 2000 and 2011. The 10-day rainfall prior to peak accounted for $30 \%$ and 35\%, while rainfall from 11 to 30 days was identified by $37 \%$ and $32 \%$ for 2000 for 2011 , respectively. Another $31 \%$ of flow at peak time for both flood events were from rainfall in 31-100 days prior to peak time. The contribution of rainfall from 31-60 to 61-100 days was $16 \%$ and $15 \%$ for the 2000 flood and $21 \%$ and $10 \%$ for the 2011 flood. Only the remaining $2 \%$ of flow was contributed by rainfall before 100 days before the peak (pie charts in Fig. 6).

The spatial zones in Fig. 7 were classified into four sub-areas to identify their sources of origination: Upper Mekong Basin from China and Myanmar from upstream to Jinghong (pink, noted as zone 1), northern Lao PDR from Jinghong to Vientiane (blue, noted as zone 2), southern Lao PDR and eastern Thailand from Vientiane to Khong Chiam (green, noted as zone 3), and the area in Cambodia and Vietnam (red, noted as zone 4) with the 

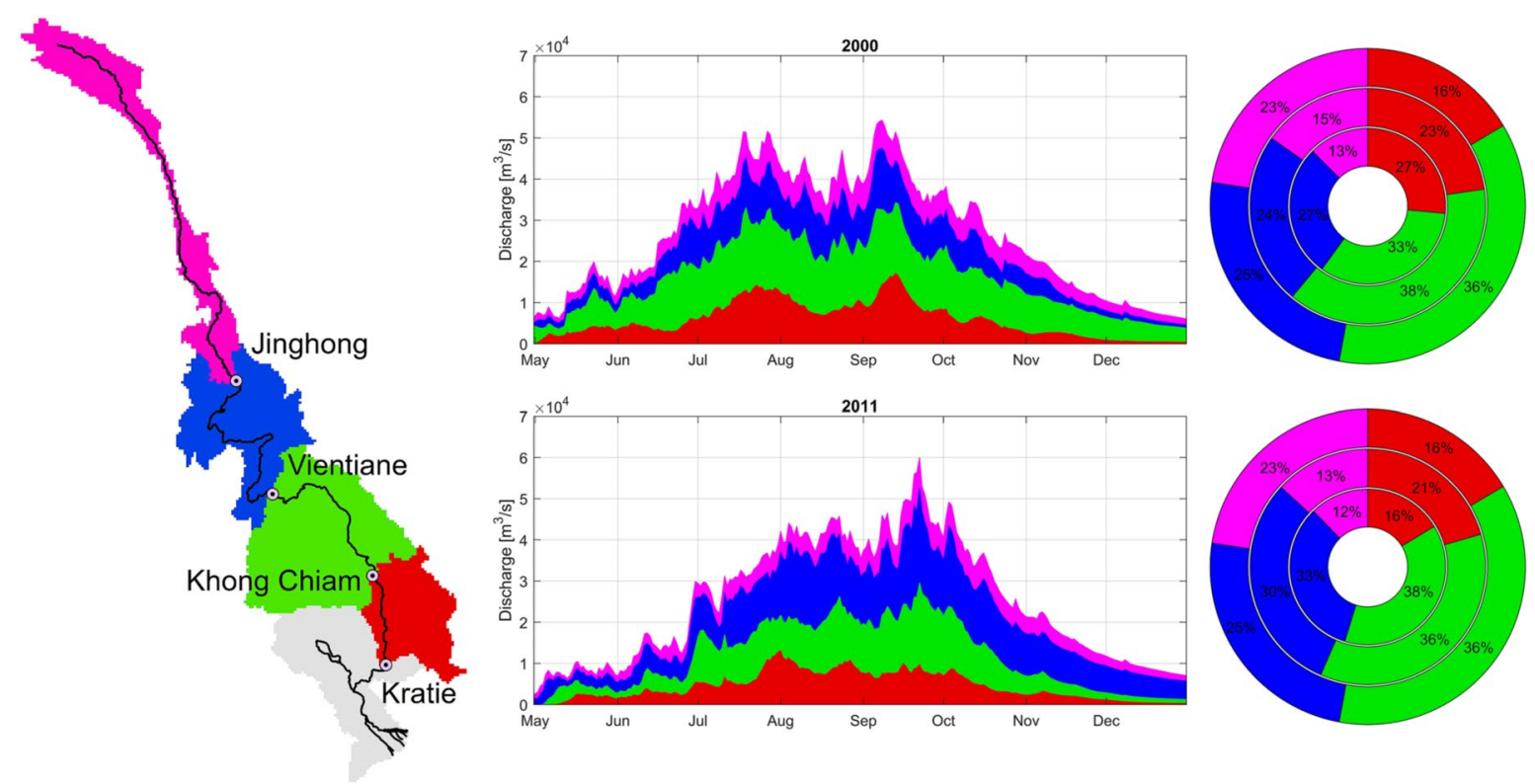

Fig. 7 Hydrograph separation for the spatial zone for flow at Kratie. The right donut graphs indicate the ratio of the area from each zone compared to the area of the upstream of Kratie station (outer ring), the ratio of discharge source from each zone for the 100-day prior to peak time (middle ring), and the ratio at the peak discharge source from each zone (inner ring) for flood events in 2000 and 2011

total area sizes of $145,593 \mathrm{~km}^{2}(23 \%), 158,044 \mathrm{~km}^{2}(25 \%)$, $234,826 \mathrm{~km}^{2}(36 \%)$, and $106,223 \mathrm{~km}^{2}(16 \%)$, respectively. This study focused on spatial separation for hydrograph at a hydrological station at Kratie in the LMB for flood events in 2000 and 2011. Figure 7 shows the spatial separation results of discharge at Kratie from May to December of the T-SAS simulation. The total annual discharges originated from zones $1,2,3$, and 4 by $21 \%, 40 \%, 22 \%$, and $17 \%$ for the 2000 flood and $18 \%, 28 \%, 39 \%$, and $15 \%$ for the 2011 flood. In addition, we evaluated the sources of flow during the peak time and the period of 100 days prior to peak time as illustrated in donut charts in Fig. 7. At the peak discharges of $54,319 \mathrm{~m}^{3} / \mathrm{s}$ on September 8 , 2000, the source of flooding was from zones 1,2, 3, and 4 by $13 \%, 27 \%, 33 \%$, and $27 \%$, while the peak of 60,007 on September 22, 2011 was contributed by $12 \%, 33 \%, 38 \%$, and $16 \%$. The contributions of sources from each zone to 100 days of flow prior to peak time were $15 \%, 24 \%, 38 \%$, and $23 \%$ for the 2000 flood and $13 \%, 30 \%, 36 \%$, and $21 \%$ for the 2011 flood.

\section{Discussion}

\section{Effect of precipitation on 2000 and 2011 floods compared} to other years

In addition to the identification of spatio-temporal information of flood events in 2000 and 2011, we assessed the effect of precipitation contribution from each spatial zone at the two periods of 30 days and 100 days prior to the peak time as the majority contributed to the peak discharge. Figure 8 and Table 2 compare the amount of precipitation within 30 days and 100 days prior to the peak discharge in each spatial zones of $1,2,3$, and 4 from 1982 to 2016 . The 30-day rainfall amount prior to peak time of discharge was $+25 \%,-36 \%,-20 \%$, and $+21 \%$ for 2000 and $-25 \%,-17 \%,+14 \%$, and $+31 \%$ for 2011 for zones $1,2,3$, and 4 compared to the average of 30-day rainfall of 35 years (Table 2). The total of 30-day rainfall of all four zones did not show significant variation (i.e., 184 billion $\mathrm{m}^{3}(-12 \%)$ for 2000 and 218 billion $\mathrm{m}^{3}(+5 \%)$ for 2011$)$ compared to the average of 208 billion $\mathrm{m}^{3}$. However, there was a significant increase of 100 day precipitation prior to the peak time of discharge for both 2000 and 2011. The increased rainfall of the total of four zones was $+12 \%$ and $+20 \%$ for 2000 and 2011, respectively. For 2000, the dominant increase was from zone 4 with an increase up to $+36 \%$, while increases in zones 1,2 , and 3 were only $+10 \%,+1 \%$, and $+9 \%$. There was an almost equal increase in rainfall amount in zones 2 , 3, and $4(+24 \%,+26 \%$, and $+23 \%)$, while there was a decrease in precipitation from zone $1(-14 \%)$ compared to the average of 35-year rainfall.

\section{Comparison of upstream flow and local rainfall on inundated water in the LMB}

The separations of fluvial and pluvial sources of inundation in the LMB in 2000 and 2011 were obtained from the results of the RRI model simulation by considering upstream flow and local rainfall and ET. Figure 9 shows 

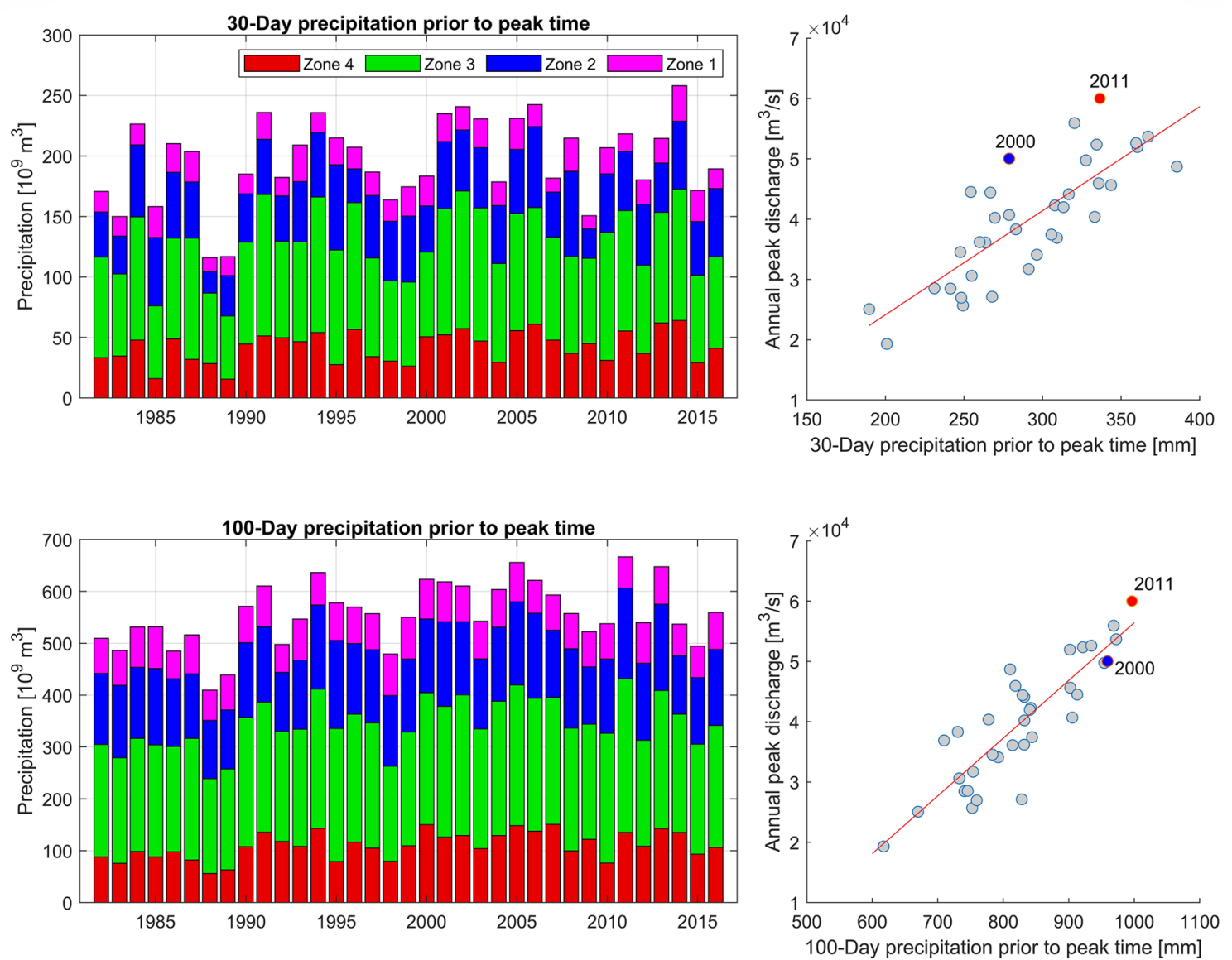

Fig. 8 Comparison of 30-day and 100-day precipitation prior to peak time from each spatial zone as in Fig. 7 of 2000 and 2011 floods compared with other years during 1982-2016. The right scatter plots are the relationship between annual peak discharge and precipitation from 30-day and 100-day prior to peak time from each 35 year

the daily inundation water volume in the LMB from fluvial and pluvial floodings from May to December in 2000 and 2011. During the two flooding events, fluvial flooding water showed a similar volume accounting for $36 \%$ and $35 \%$, and the pluvial flooding water accounted for $64 \%$ and $65 \%$ for 2000 and 2011, respectively. The results indicated that the majority source of inundation water in the LMB are from local precipitation (64-65\%); however, during the peak inundation with a water volume of $134 \mathrm{~km}^{3}$ in 2000 and $148 \mathrm{~km}^{3}$ in 2011, the fluvial inundation water increases its capacity $41-42 \%$, while the inundation distribution from pluvial flooding was only $58-59 \%$. Figure 10 illustrates the spatial distribution during the peak inundation with its fluvial and pluvial sources.

\section{Summary and conclusion}

The spatio-temporal information on the sources of rainfall provides a basic understanding of water dynamics in the river basin and flooding information. Identifying when and where of rainfall which contributes to cause the flooding is a challenging task and limitation of studies nowadays. In addition, the understanding of fluvial and pluvial sources of floodings would provide information on flood characteristics and support the preparation of countermeasures to severe flood damage reduction.

By the integrated application of a fully distributed flood inundation (RRI) and a time-space accounting scheme (T-SAS) method, the time and space separations of the sources of river discharge in the Mekong River Basin (MRB) were investigated. Moreover, this study estimated the fundamental sources of river discharge and inundated water during the large historical flooding events in 2000 and 2011 in the Lower Mekong Basin (LMB). The key findings from this study are the following:

- During flood periods from May to December for flood events in 2000 and 2011, the major sources of peak flow in Kratie came from 30-day (67\%) and 
Table 2 Comparison of 30-day and 100-day precipitaiton for each spatial zone from 1982 to 2016

\begin{tabular}{|c|c|c|c|c|c|c|c|c|c|c|}
\hline \multirow[t]{2}{*}{ Year } & \multicolumn{4}{|c|}{ 30-day precipitation $\left[10^{9} \mathrm{~m}^{3}\right]$} & \multirow[t]{2}{*}{ Total } & \multicolumn{4}{|c|}{ 100-day precipitation $\left[10^{9} \mathrm{~m}^{3}\right]$} & \multirow[t]{2}{*}{ Total } \\
\hline & Zone 1 & Zone 2 & Zone 3 & Zone 4 & & Zone 1 & Zone 2 & Zone 3 & Zone 4 & \\
\hline 1982 & 17 & 37 & 83 & 33 & & 68 & 137 & 217 & 88 & \\
\hline 1983 & 16 & 31 & 68 & 35 & & 67 & 140 & 204 & 75 & \\
\hline 1984 & 17 & 59 & 102 & 48 & & 78 & 137 & 218 & 99 & \\
\hline 1985 & 26 & 56 & 60 & 16 & & 81 & 147 & 216 & 88 & \\
\hline 1986 & 24 & 54 & 83 & 49 & & 53 & 131 & 203 & 98 & \\
\hline 1987 & 25 & 46 & 100 & 32 & & 75 & 124 & 234 & 82 & \\
\hline 1988 & 12 & 18 & 58 & 29 & & 58 & 112 & 183 & 56 & \\
\hline 1989 & 16 & 33 & 52 & 16 & & 68 & 114 & 195 & 63 & \\
\hline 1990 & 16 & 40 & 84 & 45 & & 70 & 144 & 249 & 108 & \\
\hline 1991 & 22 & 46 & 117 & 51 & & 79 & 145 & 251 & 136 & \\
\hline 1992 & 15 & 38 & 80 & 50 & & 54 & 113 & 213 & 118 & \\
\hline 1993 & 30 & 50 & 82 & 46 & & 79 & 133 & 226 & 108 & \\
\hline 1994 & 17 & 53 & 112 & 54 & & 63 & 162 & 269 & 143 & \\
\hline 1995 & 22 & 70 & 95 & 28 & & 73 & 170 & 256 & 79 & \\
\hline 1996 & 18 & 28 & 105 & 57 & & 71 & 136 & 247 & 117 & \\
\hline 1997 & 19 & 52 & 81 & 34 & & 69 & 141 & 242 & 105 & \\
\hline 1998 & 18 & 49 & 66 & 31 & & 80 & 136 & 183 & 80 & \\
\hline 1999 & 24 & 55 & 69 & 26 & & 81 & 141 & 219 & 109 & \\
\hline 2000 & $25(+25 \%)$ & $38(-36 \%)$ & $70(-20 \%)$ & $51(+21 \%)$ & $184(-12 \%)$ & 77 (+10\%) & $142(+1 \%)$ & $255(+9 \%)$ & $150(+36 \%)$ & $624(+12 \%)$ \\
\hline 2001 & 23 & 56 & 104 & 52 & & 77 & 163 & 252 & 126 & \\
\hline 2002 & 19 & 51 & 114 & 57 & & 69 & 141 & 271 & 129 & \\
\hline 2003 & 24 & 50 & 110 & 47 & & 73 & 135 & 231 & 104 & \\
\hline 2004 & 20 & 48 & 82 & 29 & & 73 & 143 & 259 & 129 & \\
\hline 2005 & 26 & 53 & 97 & 56 & & 76 & 160 & 271 & 148 & \\
\hline 2006 & 18 & 67 & 96 & 61 & & 63 & 164 & 256 & 138 & \\
\hline 2007 & 12 & 37 & 85 & 48 & & 68 & 130 & 245 & 151 & \\
\hline 2008 & 27 & 70 & 80 & 37 & & 68 & 153 & 237 & 100 & \\
\hline 2009 & 11 & 24 & 70 & 45 & & 68 & 111 & 222 & 122 & \\
\hline 2010 & 22 & 48 & 106 & 31 & & 68 & 143 & 250 & 76 & \\
\hline 2011 & $15(-25 \%)$ & $49(-17 \%)$ & $99(+14 \%)$ & $55(+31 \%)$ & $218(+5 \%)$ & $60(-14 \%)$ & 175 (24\%) & $296(+26 \%)$ & $135(+23 \%)$ & $666(+20 \%)$ \\
\hline 2012 & 20 & 50 & 73 & 37 & & 78 & 148 & 204 & 108 & \\
\hline 2013 & 20 & 41 & 91 & 62 & & 72 & 166 & 266 & 143 & \\
\hline 2014 & 30 & 56 & 109 & 64 & & 61 & 112 & 228 & 136 & \\
\hline 2015 & 26 & Zone 2 & 72 & 29 & & 61 & 128 & 212 & 93 & \\
\hline 2016 & 16 & 37 & 76 & 41 & & 71 & 146 & 235 & 106 & \\
\hline Avg & 20 & 59 & 87 & 42 & 208 & 70 & 141 & 235 & 110 & 556 \\
\hline
\end{tabular}

The values in brackets in 2000 and 2011 represent the relative value of increase (+) or decrease (-) compared to the average value of all 35 -year data

100-day (98\%) precipitation in the upstream drainage area.

- The area ratio of the Chinese Upper Mekong (zone 1), northern Lao PDR (zone 2), southern Lao PDR and eastern Thailand (zone 3), and Cambodia and Vietnam (zone 4) of 23\%, 25\%, 36\%, and 16\% contributed to peak flow at Kratie by $13 \%, 27 \%, 33 \%$, and $27 \%$ for the 2000 flood and 12\%, 33\%, 38\%, and 16\% for the 2011 flood.
- The main factor causing the 2000 flood was a large amount of 100-day rainfall in zone 4 prior to peak discharge at Kratie, while the large rainfall amount was observed in zones 2, 3, and 4 driving the high flow in the 2011 flood.

- The inundation water in the LMB was 35-36\% from the upstream flow (fluvial source) and 64-65\% from the local rainfall (pluvial source). 

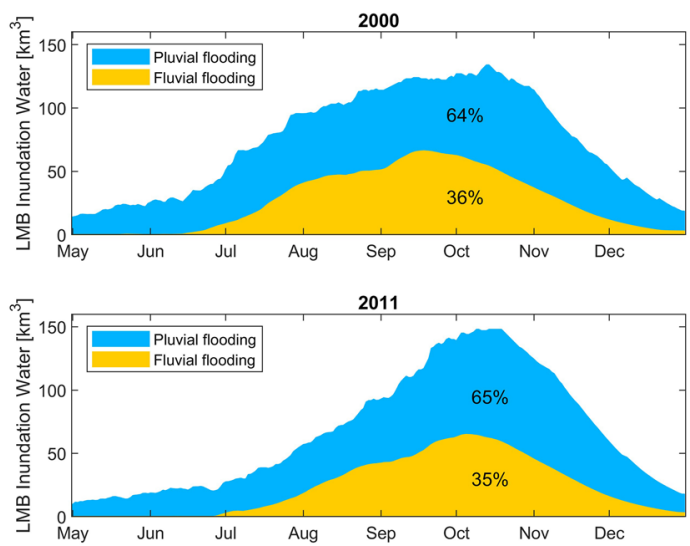

Fig. 9 Separation of pluvial and fluvial sources of inundation water from May to December for 2000 and 2011
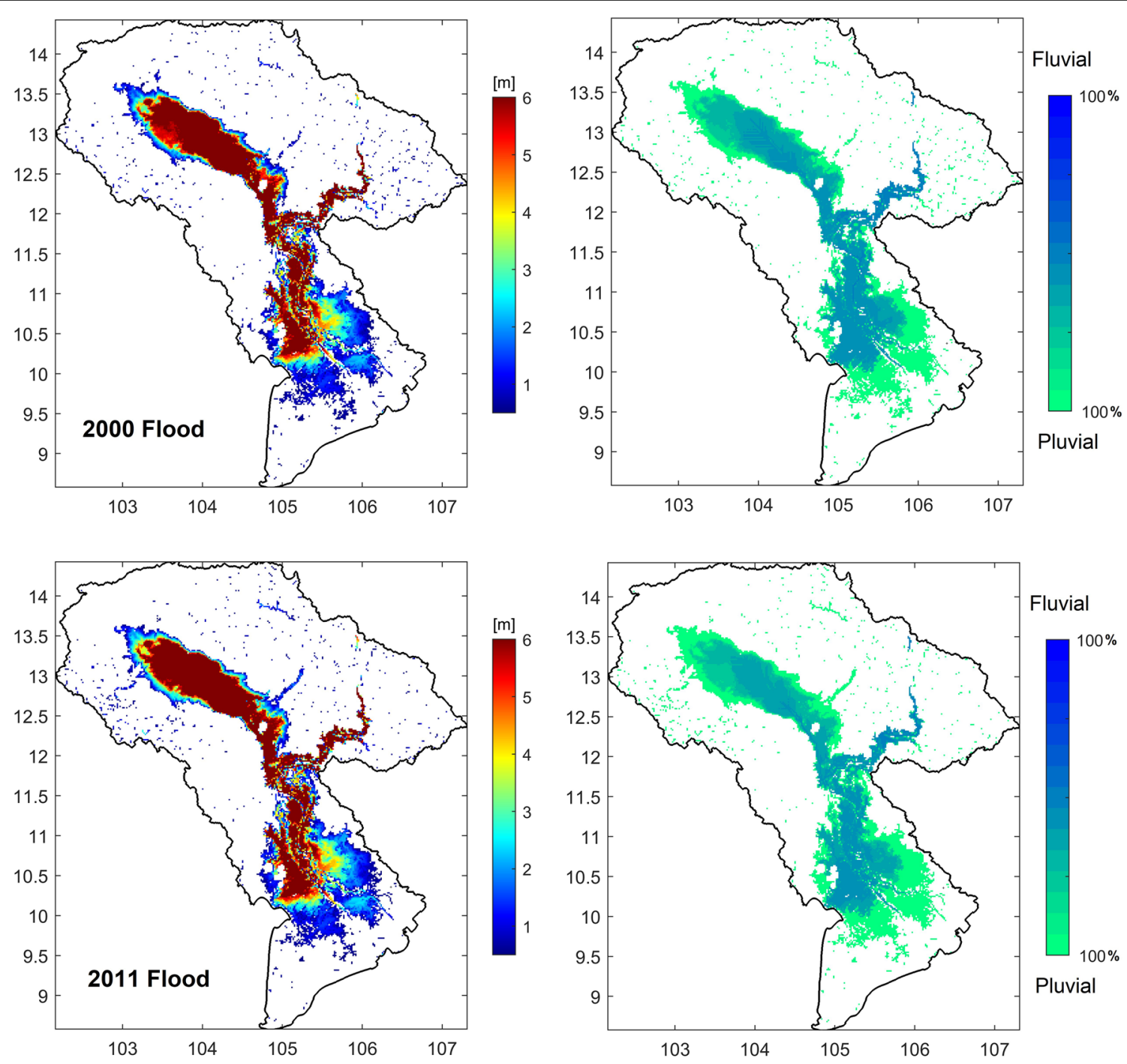

Fluvial

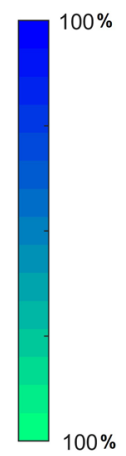

Pluvial

Fig. 10 Fluvial and pluvial sources of inundation in the LMB in 2000 and 2011 


\section{Acknowledgements}

The authors thank to the Mekong River Commission for providing observed hydrological data for this study.

\section{Authors' contributions}

ST: conceptualization, methodology, writing draft manuscript, modeling, data visualization. TS: methodology, revising manuscript, research supervision, funding acquisition. CO: observed hydrological data collection, revising manuscript, funding acquisition. TS: observed hydrological data collection, revising manuscript. SL: revising manuscript. SU: writing draft manuscript, revising manuscript. All authors read and approved the final manuscript.

\section{Funding}

This research was supported by the Japan Society for the Promotion of Science (JSPS) KAKENHI Grant-in-Aid id: 21F21071 and Cambodia Higher Education Improvement Project (Credit No. 6221-KH).

\section{Availability of data and materials}

The datasets used and analyzed during the current study are available from the corresponding author on reasonable request.

\section{Declarations}

\section{Competing interests}

The authors declare that they have no competing interests.

\section{Author details}

'Disaster Prevention Research Institute, Kyoto University, Kyoto, Japan. ${ }^{2}$ Faculty of Hydrology and Water Resources Engineering, Institute of Technology of Cambodia, Phnom Penh, Cambodia. ${ }^{3}$ Department of Civil and Environmental Engineering, Tokyo Institute of Technology, Tokyo, Japan.

Received: 3 August 2021 Accepted: 9 January 2022

Published online: 29 January 2022

\section{References}

ADB (2012) Flood damage emergency reconstruction: preliminary damage and loss assessment. Asian Development Bank

Bhagabati SS, Kawasaki A (2017) Consideration of the rainfall-runoff-inundation (RRI) model for flood mapping in a deltaic area of Myanmar. Hydrol Res Lett 11:155-160. https://doi.org/10.3178/hrl.11.155

Buttle JM (1994) Isotope hydrograph separations and rapid delivery of preevent water from drainage basins. Prog Phys Geogr 18:16-41. https://doi. org/10.1177/030913339401800102

Cash JR, Karp AH (1990) A variable order Runge-Kutta method for initial value problems with rapidly varying right-hand sides. ACM Trans Math Softw 16:201-222

Chong KL, Sayama T, Takara K, Abustan I (2017) Effects of diffusive wave and flood inundation on time of concentration. J Jpn Soc Civil Eng 73:I_151I_56. https://doi.org/10.2208/jscejhe.73.I_151

Duan W, He B, Nover D et al (2016) Floods and associated socioeconomic damages in China over the last century. Nat Hazards 82:401-413

Duan W, Chen Y, Zou S, Nover D (2019) Managing the water-climate-food nexus for sustainable development in Turkmenistan. J Clean Prod 220:212-224

Duan W, Zou S, Chen Y et al (2020) Sustainable water management for crossborder resources: the Balkhash Lake Basin of Central Asia, 1931-2015. J Clean Prod 263:121614. https://doi.org/10.1016/j.jclepro.2020.121614

Friedl MA, Sulla-Menashe D, Tan B et al (2010) MODIS collection 5 global land cover: algorithm refinements and characterization of new datasets. Remote Sens Environ 114:168-182

Halofsky JE, Peterson DL, Ho JJ, et al (2018) Climate change vulnerability and adaptation in the Intermountain Region [Part 1]. Gen Tech Rep RMRSGTR-375 Fort Collins, CO: US Department of Agriculture, Forest Service, Rocky Mountain Research Station p 1-197 375:1-197. https://doi.org/10. 2737/RMRS-GTR-375PART1
IPCC (2014) Synthesis Report. Contribution of Working Groups I, II and III to the Fifth Assessment Report of the Intergovernmental Panel on Climate Change. IPCC, Geneva, Switzerland

Jain CK, Singh S (2018) Impact of climate change on the hydrological dynamics of River Ganga, India. J Water Clim Change 11:274-290. https://doi. org/10.2166/wcc.2018.029

Khaing ZM, Zhang K, Sawano H et al (2019) Flood hazard mapping and assessment in data-scarce Nyaungdon area, Myanmar. PLoS ONE 14:e0224558. https://doi.org/10.1371/journal.pone.0224558

Kobayashi S, Ota Y, Harada Y et al (2015) The JRA-55 reanalysis: general specifications and basic characteristics. J Meteorol Soc Jpn Ser II 93:5-48

Mei Y, Anagnostou EN (2015) A hydrograph separation method based on information from rainfall and runoff records. J Hydrol 523:636-649. https://doi.org/10.1016/j.jhydrol.2015.01.083

Moftakhari HR, AghaKouchak A, Sanders BF, Matthew RA (2017) Cumulative hazard: the case of nuisance flooding. Earth's Future 5:214-223. https:// doi.org/10.1002/2016EF000494

MRC (2005) Overview of the hydrology of the Mekong Basin. Mekong River Commission, Vientiane, Lao PDR

MRC (2015) Annual Mekong Flood Report 2011. Mekong River Commission, Vientiane, Lao PDR, 72 pages

Muir MJ, Luce CH, Gurrieri JT, et al (2018) Effects of climate change on hydrology, water resources, and soil [Chapter 4]. In: Halofsky, Jessica E; Peterson, David L; Ho, Joanne J; Little, Natalie, J; Joyce, Linda A, eds Climate change vulnerability and adaptation in the Intermountain Region [Part 1] Gen Tech Rep RMRS-GTR-375 Fort Collins, CO: US Department of Agriculture, Forest Service, Rocky Mountain Research Station p 60-88 375:60-88

Pelletier A, Andréassian V (2020) Hydrograph separation: an impartial parametrisation for an imperfect method. Hydrol Earth Syst Sci 24:1171-1187. https://doi.org/10.5194/hess-24-1171-2020

Pendergrass AG, Knutti R, Lehner F et al (2017) Precipitation variability increases in a warmer climate. Sci Rep 7:17966. https://doi.org/10.1038/ s41598-017-17966-y

Perera EDP, Sayama T, Magome J et al (2017) RCP8.5-based future flood hazard analysis for the Lower Mekong River Basin. Hydrology 4:55. https://doi. org/10.3390/hydrology4040055

Rasmy M, Sayama T, Koike T (2019) Development of water and energy budgetbased rainfall-runoff-inundation model (WEB-RRI) and its verification in the Kalu and Mundeni River Basins, Sri Lanka. J Hydrol 579:124163. https://doi.org/10.1016/j.jhydrol.2019.124163

Sayama T, McDonnell JJ (2009) A new time-space accounting scheme to predict stream water residence time and hydrograph source components at the watershed scale. Water Resour Res 45

Sayama T, Ozawa G, Kawakami T et al (2012) Rainfall-runoff-inundation analysis of the 2010 Pakistan flood in the Kabul River basin. Hydrol Sci J 57:298-312. https://doi.org/10.1080/02626667.2011.644245

Sayama T, Tatebe Y, Iwami Y, Tanaka S (2015a) Hydrologic sensitivity of flood runoff and inundation: 2011 Thailand floods in the Chao Phraya River basin. Nat Hazard 15:1617-1630. https://doi.org/10.5194/ nhess-15-1617-2015

Sayama T, Tatebe Y, Tanaka S (2015b) An emergency response-type rainfallrunoff-inundation simulation for 2011 Thailand floods. J Flood Risk Manage 10:65-78. https://doi.org/10.1111/jfr3.12147

Sayama T, Matsumoto K, Kuwano Y, Takara K (2019) Application of backpackmounted mobile mapping system and rainfall-runoff-inundation model for flash flood analysis. Water 11:963. https://doi.org/10.3390/w11050963

Sayama T, Yamada M, Sugawara Y, Yamazaki D (2020) Ensemble flash flood predictions using a high-resolution nationwide distributed rainfall-runoff model: case study of the heavy rain event of July 2018 and Typhoon Hagibis in 2019. Prog Earth Planet Sci 7:75. https://doi.org/10.1186/ s40645-020-00391-7

Tam TH, Abd Rahman MZ, Harun S et al (2019) Application of satellite rainfall products for flood inundation modelling in Kelantan River Basin, Malaysia. Hydrology 6:95. https://doi.org/10.3390/hydrology6040095

Tan SB, Lo EY-M, Shuy EB et al (2009) Hydrograph separation and development of empirical relationships using single-parameter digital filters. J Hydrol Eng 14:271-279. https://doi.org/10.1061/(ASCE)1084-0699(2009) 14:3(271)

Tanaka T, Kiyohara K, Tachikawa Y (2020) Comparison of fluvial and pluvial flood risk curves in urban cities derived from a large ensemble climate 
simulation dataset: a case study in Nagoya, Japan. J Hydrol 584:124706. https://doi.org/10.1016/j.jhydrol.2020.124706

Try S, Lee D, Lee G (2018a) Application of nightlight satellite imagery for assessing flooding potential area in the Mekong river basin. J Korea Water Resour Assoc. 51:565-574. https://doi.org/10.3741/JKWRA.2018.51.7.565

Try S, Lee G, Yu W et al (2018b) Large-scale flood-inundation modeling in the Mekong River Basin. J Hydrol Eng 23:05018011. https://doi.org/10.1061/ (ASCE)HE.1943-5584.0001664

Try S, Lee G, Yu W, Oeurng C (2019) Delineation of flood-prone areas using geomorphological approach in the Mekong River Basin. Quatern Int 503:79-86. https://doi.org/10.1016/j.quaint.2018.06.026

Try S, Tanaka S, Tanaka K et al (2020a) Projection of extreme flood inundation in the Mekong River basin under 4K increasing scenario using large ensemble climate data. Hydrol Process 34:4350-4364. https://doi.org/10. 1002/hyp.13859

Try S, Tanaka S, Tanaka K et al (2020b) Comparison of gridded precipitation datasets for rainfall-runoff and inundation modeling in the Mekong River Basin. PLoS ONE 15:e0226814. https://doi.org/10.1371/journal.pone. 0226814

Try S, Tanaka S, Tanaka K et al (2020c) Assessing the effects of climate change on flood inundation in the lower Mekong Basin using high-resolution AGCM outputs. Prog Earth Planet Sci 7:34. https://doi.org/10.1186/ s40645-020-00353-z

Uhlenbrook S, Hoeg S (2003) Quantifying uncertainties in tracer-based hydrograph separations: a case study for two-, three- and five-component hydrograph separations in a mountainous catchment. Hydrol Process 17:431-453. https://doi.org/10.1002/hyp.1134

Wu W-Y, Lo M-H, Wada Y et al (2020) Divergent effects of climate change on future groundwater availability in key mid-latitude aquifers. Nat Commun 11:3710. https://doi.org/10.1038/s41467-020-17581-y

Yamamoto EMS, Sayama T, Yamamoto K (2020) Comparison of runoff generation methods for land use impact assessment using the SWAT model in humid tropics. Hydrol Res Lett 14:81-88. https://doi.org/10.3178/hrl.14.81

Yamazaki D, Ikeshima D, Tawatari R et al (2017) A high-accuracy map of global terrain elevations. Geophys Res Lett 44:5844-5853

Ziese M, Rauthe-Schöch A, Becker A, et al (2018) GPCC full data daily version. 2018 at 1.00: Daily land-surface precipitation from rain-gauges built on GTS-based and historic data. GPCC Full Data Daily Version 2018 at $10^{\circ}$ : Daily Land-Surface Precipitation from Rain-Gauges Built on GTS-Based and Historic Data

Zou S, Abuduwaili J, Ding J, et al (2020) Description and attribution analysis of the 2017 spring anomalous high temperature causing floods in Kazakhstan. Journal of the Meteorological Society of Japan Ser II

\section{Publisher's Note}

Springer Nature remains neutral with regard to jurisdictional claims in published maps and institutional affiliations.

\section{Submit your manuscript to a SpringerOpen ${ }^{\odot}$ journal and benefit from:}

- Convenient online submission

- Rigorous peer review

- Open access: articles freely available online

- High visibility within the field

- Retaining the copyright to your article

Submit your next manuscript at $\mathbf{s p r i n g e r o p e n . c o m ~}$ 